\title{
Planococcus halocryophilus sp. nov., an extreme sub-zero species from high Arctic permafrost
}

\author{
Correspondence \\ Lyle G. Whyte \\ Lyle.Whyte@mcgill.ca
}

\author{
Nadia C. S. Mykytczuk, Roland C. Wilhelm and Lyle G. Whyte \\ Department of Natural Resource Sciences, McGill University, OC H9X 3V9, Canada
}

Following the description of the genus Planococcus by Migula (1894), several amendments to this description were made by Nakagawa et al. (1996) and more recently by Yoon et al. (2010). At the time of writing, the genus Planococcus comprised nine recognized species: Planococcus citreus (Kocur et al., 1970), Planococcus kocurii (Hao \& Komagata, 1985), Planococcus antarcticus (Reddy et al., 2002), Planococcus rifietoensis (Romano et al., 2003), Planococcus maritimus (Yoon et al., 2003), Planococcus maitriensis (Alam et al., 2003), Planococcus columbae (Suresh et al., 2007), Planococcus donghaensis (Choi et al., 2007) and Planococcus salinarum (Yoon et al., 2010). Five additional species originally allocated to the genus Planococcus, namely Planococcus okeanokoites (Nakagawa et al., 1996), Planococcus mcmeekinii (Junge et al., 1998), Planococcus alkanoclasticus (Engelhardt et al., 2001), Planococcus psychrophilus (Reddy et al., 2002) and Planococcus stackebrandtii (Mayilraj et al., 2005), were subsequently transferred to the genus Planomicrobium (Yoon et al., 2001; Dai et al., 2005; Jung et al., 2009). All members of the genus Planococcus are Gram-positive, aerobic cocci that are able to grow at moderately low temperatures and high salt concentrations, and have been predominantly isolated from cold and/or

The GenBank/EMBL/DDBJ accession number for the 16S rRNA gene sequence of strain $\operatorname{Or} 1^{\top}$ is JF742665. saline environments (Arctic, Antarctic, marine). Chemotaxonomic, phylogenetic and physiological characterization and classification of a novel Planococcus-like strain, $\operatorname{Or} 1^{\mathrm{T}}$, presented in this paper indicate that it represents a novel species of the genus Planococcus with the broadest cold and salt tolerance reported to date, most notably growing at subzero temperatures.

Bacterial strain $\operatorname{Or}^{\mathrm{T}}$ was isolated from active-layer soil, at a depth of $<1 \mathrm{~m}$, sampled from a soil core (Eur3) taken at Eureka, Ellesmere Island, in the Canadian high Arctic (Steven et al., 2007). Strain Or1 ${ }^{\mathrm{T}}$ was isolated from $5 \mathrm{~g}$ aseptically collected permafrost (Juck et al., 2005; Steven et al., 2008) along with several other permafrost bacteria following enrichment in R2A media (Difco) supplemented with sodium acetate $\left(0.4 \mathrm{~g} \mathrm{l}^{-1}\right)$ incubated at $5{ }^{\circ} \mathrm{C}$. Following 11 months of incubation, $100 \mu$ culture was transferred to $\mathrm{R} 2 \mathrm{~A}$ agar solid media at $5{ }^{\circ} \mathrm{C}$ (Difco), resulting in the isolation of individual colonies, including strain $\operatorname{Or}^{\mathrm{T}}$. Routine cultivation of strain $\mathrm{Orl}^{\mathrm{T}}$ was carried out in trypticase soy agar (TSA; Difco) or broth (TSB; Difco) at room temperature $\left(23-25{ }^{\circ} \mathrm{C}\right)$, and the strain was maintained in $25 \%$ glycerol stocks at $-80{ }^{\circ} \mathrm{C}$. Interest in the extreme cold growth of strain Or $1^{\mathrm{T}}$ prompted sequencing of the complete genome (454 pyrosequence+Illumina consensus sequence) referred to in parts of this paper (N. C. S. Mykytczuk and others, unpublished results). 
A summary of the morphological and physiological traits of strain $\mathrm{Or} 1^{\mathrm{T}}$ compared with those of the type strains of recognized Planococcus species is presented in Table 1. Cell morphology and Gram reaction of strain $\mathrm{Or} 1^{\mathrm{T}}$ were determined microscopically by using a Nikon Eclipse E600 microscope on cells grown in TSB. Gram staining was performed with a BD Gram stain kit and spore formation with the Schaeffer and Fulton Spore Stain kit (Fluka Analytical, Sigma-Aldrich). Cells of strain $\operatorname{Or}^{T}{ }^{T}$ were consistently Gram-positive and no spores were observed following staining of colonies grown for 48 and $72 \mathrm{~h}$, and up to 1 week. Micrographs were also obtained by transmission and scanning electron microscopy with samples prepared as described by Vali et al. (2004). Cells of strain Or ${ }^{\mathrm{T}}$ were coccoid, typically $0.8-1.2 \mu \mathrm{m}$ in diameter, arranged singly or as diplococci (Fig. 1). Motility was assessed by microscopic examination of wet mounts over the period of incubation at both room temperature and at $5{ }^{\circ} \mathrm{C}$. Cells of strain $\operatorname{Or} 1^{\mathrm{T}}$ were motile under the observed conditions, as with most recognized Planococcus species (Table 1). Initial screening of the genome sequence indicated the presence of a flagellar synthesis operon, but this has not yet been confirmed as functional (N. C. S. Mykytczuk and others, unpublished results). Colony morphology was determined on TSA plates following 2-3 days growth at $25{ }^{\circ} \mathrm{C}$, which resulted in the formation of orange, round, convex colonies with a raised centre. Colony morphology changed with increasing salt concentration and at sub-zero temperatures (only TSA plates with $5 \%$ sucrose were tested at $-5{ }^{\circ} \mathrm{C}$ ) leading to smaller or more irregular, umbonate colonies, respectively.

Further physiological and biochemical characterizations of strain Or $1^{\mathrm{T}}$ were completed under specified growth conditions and are summarized relative to recognized Planococcus species in Table 1. Growth temperature limits for strain $\mathrm{Or} 1^{\mathrm{T}}$ were determined on TSA media incubated at $0-30{ }^{\circ} \mathrm{C}$ (increments of $5{ }^{\circ} \mathrm{C}$ ), and also at $32,35,37,38,39$ and $40{ }^{\circ} \mathrm{C}$. Growth occurred at all temperatures up to and including $37{ }^{\circ} \mathrm{C}$. Growth at sub-zero temperatures was determined in TSB liquid cultures supplemented with $\mathrm{NaCl}$ and glycerol for $-5{ }^{\circ} \mathrm{C}(5 \% \mathrm{NaCl}, 2 \%$ glycerol $)$ and $-10{ }^{\circ} \mathrm{C}(12 \% \mathrm{NaCl}, 5 \%$ glycerol). Growth was confirmed by an increase in turbidity monitored spectrophotometrically at OD $480 \mathrm{~nm}$ (wavelength adjusted for glycerol), viable plate counting on TSA plates, as well as an accumulation of sedimented cells over weeks and months of incubation at -5 and $-10{ }^{\circ} \mathrm{C}$, respectively. Growth below $-10{ }^{\circ} \mathrm{C}$ appeared possible, but additional media amendments were required and were not explored as part of this study. The unique sub-zero growth capacity appears to be linked to the ability of strain $\operatorname{Orl}^{\mathrm{T}}$ to tolerate a highsalinity brine that remains liquid at low temperatures and corresponds with genome-encoded traits conferring cold and salinity tolerance (N. C. S. Mykytczuk and others, unpublished results). The $\mathrm{pH}$ range for growth of strain Or $1^{\mathrm{T}}$ was determined on R2A agar or TSA plates adjusted with either $\mathrm{HCl}$ or $\mathrm{NaCO}_{3}$ to give a final $\mathrm{pH}$ ranging from
4.5 to 12.0 at $0.5 \mathrm{pH}$ unit increments, and incubated at $25{ }^{\circ} \mathrm{C}$. Growth was observed within the range $\mathrm{pH}$ 6.0-11.0, but not at higher or lower $\mathrm{pH}$. Salt tolerance was determined on TSA media supplemented with $0-22 \%$ $(\mathrm{w} / \mathrm{v}) \mathrm{NaCl}$ in increments of 1 or $2 \%$ and incubated at room temperature for up to 2 weeks. Growth was observed at $\mathrm{NaCl}$ concentrations of $0-19 \%$, with optimal growth at $1.5 \% \mathrm{NaCl}$. This range is similar to that of just one recognized Planococcus species, Planococcus maritimus, with most other species showing only moderate halotolerance (Table 1).

Strain $\operatorname{Or} 1^{\mathrm{T}}$ was catalase-positive, as determined by the addition of $3 \% \mathrm{H}_{2} \mathrm{O}_{2}$ to an aliquot of active culture, with the production of bubbles indicating a positive reaction. Strain $\operatorname{Or}^{\mathrm{T}}$ was also oxidase-positive, as determined by using a BD BBL DrySlide according to the manufacturer's instructions (Becton Dickinson). Biolog Gen III Micro plates (Biolog) were used to test the ability of strain Or $1^{\mathrm{T}}$ to metabolize major classes of biochemicals and other physiological properties, including the use of various sugars, amino acids, carboxylic acids, reducing power and chemical sensitivities. Growth on different carbon sources was assessed and strain $\operatorname{Or}^{\mathrm{T}}$ was capable of utilizing glucose, rhamnose, fructose, glycerol, mannose, galactose, maltose, glucosamine, glutamine, ribose, trehalose, cellobiose, mannitol, sucrose, lactose, lactic acid, pectin, gelatin, dextrin, alanine, serine, arginine, acetic acid, glutamic acid and gluconic acid, but not raffinose, melibiose, inositol methyl pyruvate, aminobutyric acid, ketobutyric acid or bromosuccinic acid when these were provided as the only carbon source.

Results of antibiotic sensitivity included in the Biolog microplates revealed that strain $\mathrm{Or} 1^{\mathrm{T}}$ was sensitive to troleandomycin, rifamycin SV, mynocycline, lincomycin, vancomycin and nalidixic acid. Additional antibiotic sensitivity tests were performed by the addition of antibiotics to a final concentration of $100 \mathrm{mg} \mathrm{ml}^{-1}$ in TSA medium. Strain Or $1^{\mathrm{T}}$ was resistant to tetracycline, polymyxin $\mathrm{B}$, penicillin $\mathrm{G}$ and erythromycin, but sensitive to amoxicillin and streptomycin. These antibiotic sensitivities matched the profiles reported for some Planococcus species, such as Planococcus maitriensis (Alam et al., 2003), but did not fully match the susceptibility profile of related species, including Planococcus antarcticus (Reddy et al., 2002).

For characteristics not tested by the Biolog system, additional screening of acid production from carbohydrates and physiological traits were determined by using API 20E test strips according to the manufacturer's instructions (bioMérieux). Strain $\mathrm{Orl}^{\mathrm{T}}$ produced acid from glucose, mannitol, sucrose, rhamnose and L-arabinose, but not from inositol, sorbitol, melibiose or amygdalin. Aesculin, starch and Tween 80 were not hydrolysed, while gelatin was hydrolysed. Strain $\mathrm{Or}^{\mathrm{T}}{ }^{\mathrm{T}}$ was positive for $\beta$-galactosidase, citrate utilization, arginine decarboxylase, lysine decarboxylase, hydrogen sulfide and indole production, but negative for the Vogues-Proskauer test (acetylmethylcarbinol production), 
Table 1. Comparison of the phenotypic and chemotaxonomic characteristics of strain $\operatorname{Or} 1^{\top}$ and the type strains of all recognized Planococcus species

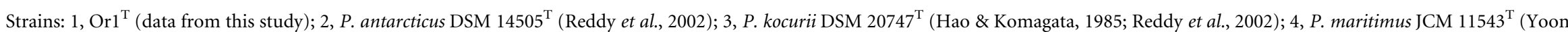

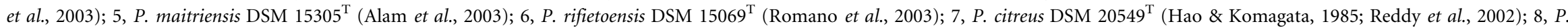

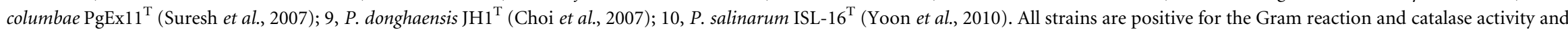
have coccoid cell morphology. All taxa are negative for spore formation and urease. $+/-$, Weakly positive; $v$, variable reaction; NR, not reported.

\begin{tabular}{|c|c|c|c|c|c|c|c|c|c|c|}
\hline Characteristic & 1 & 2 & 3 & 4 & 5 & 6 & 7 & 8 & 9 & 10 \\
\hline $\begin{array}{l}\text { Growth temperature range } \\
\left({ }^{\circ} \mathrm{C}\right)\end{array}$ & $<-10$ to 37 & $0-30$ & $4-37$ & $4-41$ & $0-40$ & $0-30$ & $5-42$ & $8-42$ & $4-37$ & $4-38$ \\
\hline Motility & + & + & + & + & + & NR & + & + & + & - \\
\hline $\mathrm{pH}$ range & $6.0-11$ & $6.0-12$ & $\mathrm{NR}$ & $5.0-8.0$ & $6.0-12$ & $6.0-10.5$ & NR & $6.0-11$ & $7.0-8.0$ & $6.0-7.5$ \\
\hline $\mathrm{NaCl}$ tolerance $(\%)$ & 19 & 12 & 3.3 & 17 & 12.5 & 15 & 10 & 14 & 12 & 13 \\
\hline Oxidase & + & - & - & - & - & + & - & - & + & + \\
\hline Nitrate reduction & - & - & - & - & + & - & - & + & - & - \\
\hline \multicolumn{11}{|l|}{ Hydrolysis of: } \\
\hline Gelatin & + & + & $\mathrm{v}$ & + & + & + & + & - & - & - \\
\hline Starch & - & - & - & - & - & - & - & - & + & - \\
\hline Casein & - & NR & NR & + & + & - & NR & - & + & + \\
\hline Tween 40 & + & NR & NR & - & - & + & + & + & NR & + \\
\hline \multicolumn{11}{|l|}{ Acid production from: } \\
\hline Glucose & + & + & $\mathrm{v}$ & + & - & - & + & - & - & - \\
\hline Mannitol & + & - & - & + & - & - & - & - & - & - \\
\hline Sucrose & + & + & - & - & $+1-$ & - & - & + & + & - \\
\hline Peptidoglycan & L-Lys-D-Glu & L-Lys-D-Glu & L-Lys-D-Glu & L-Lys-D-Glu & L-Lys-D-Glu & L-Lys-D-Glu & L-Lys-D-Glu & L-Lys-D-Glu & L-Lys-D-Glu & NR \\
\hline Menaquinone(s) & $\begin{array}{c}\text { MK-7, MK-8, } \\
\text { MK-6 }\end{array}$ & MK-7, MK-8 & MK-7, MK-8 & $\begin{array}{c}\text { MK-8, MK-7, } \\
\text { MK-6 }\end{array}$ & MK-8, MK-7 & MK-8 & MK-8, MK-7 & MK-7, MK-8 & MK-7, MK-8 & MK-8, MK-7 \\
\hline $\begin{array}{l}\text { DNA G }+ \text { C content } \\
(\mathrm{mol} \%)\end{array}$ & 40.5 & 42 & $40-43$ & 48 & 39 & 48 & $48-51$ & 50.5 & 47 & 48.3 \\
\hline
\end{tabular}



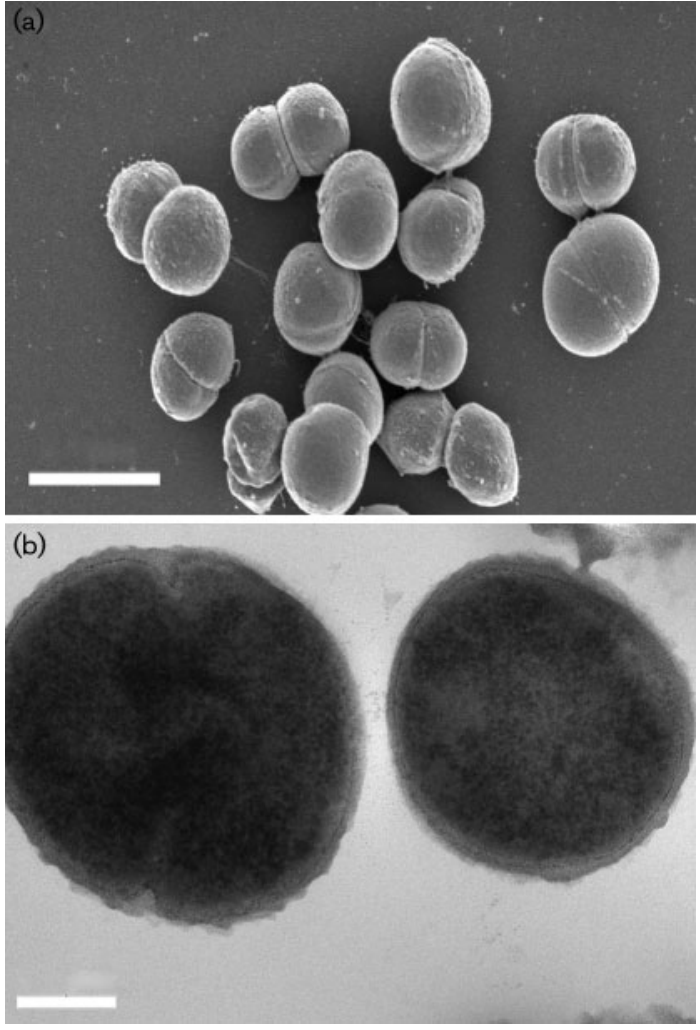

Fig. 1. Scanning (a) and transmission (b) electron micrographs of cells of strain Or $1^{\top}$ grown at $25^{\circ} \mathrm{C}$. Single cocci $(0.8-1.2 \mu \mathrm{m}$ in diameter) and diplococci are observed and cell division septa at different stages are apparent. Bars: $a, 1.5 \mu \mathrm{m} ; \mathrm{b}, 0.2 \mu \mathrm{m}$.

urease, ornithine carboxylase, tryptophan deaminase and nitrate reduction. For several of the biochemical characteristics described above, validation of necessary enzymes and pathways was performed by using the draft genome for strain $\mathrm{Or} 1^{\mathrm{T}}$ and allowed for accurate differentiation between weak or variable results (N. C. S. Mykytczuk and others, unpublished results).

Initially, the $16 \mathrm{~S}$ rRNA gene sequence was determined from DNA isolated from a single colony of strain $\operatorname{Orl}^{\mathrm{T}}$. The almost-complete $16 \mathrm{~S}$ rRNA gene sequence was PCRamplified and sequenced as outlined by Steven et al. (2008). In brief, DNA was isolated by using the Grampositive protocol of the DNeasy Blood and Tissue kit (Qiagen) and the 16S rRNA gene was PCR-amplified by using primers $27 \mathrm{~F}$ and 1492R (Lane, 1991). Subsequently, the complete $16 \mathrm{~S}$ rRNA gene sequence $(1550 \mathrm{bp})$ was extracted from the draft genome sequence (N. C. S. Mykytczuk and others, unpublished results) and used for phylogenetic analyses. The two sequences were identical in their alignment, the submitted sequence being $\sim 130 \mathrm{bp}$ longer.

The phylogenetic position of strain $\operatorname{Or}^{\mathrm{T}}$ compared with members of the genus Planococcus and the closely related
Planomicrobium clade was determined from 16S rRNA gene sequence alignments (CLUSTAL W) and phylogenetic and molecular evolutionary analyses conducted in MEGA version 5 (Tamura et al., 2011). Trees were constructed by using the neighbour-joining method (Saitou \& Nei, 1987) and Jukes-Cantor modelling (Jukes \& Cantor, 1969) with 1000 bootstrap iterations (Fig. 2). A similar topology was also obtained for the tree constructed with the maximumlikelihood algorithm. The 16S rRNA gene sequence of strain Or $1^{\mathrm{T}}$ contained the same signature nucleotides ( $\mathrm{T}$ and A at positions 183 and 190, respectively; Escherichia coli $16 \mathrm{~S}$ rRNA gene sequence numbering) as those defined for the genus Planococcus, and clustered separately from the related Planomicrobium clade (Dai et al., 2005). The phylogenetic similarity of strain $\mathrm{Or}^{\mathrm{T}}$ to recognized Planococcus species was determined from pairwise sequence comparisons by using the EzTaxon database (www.eztaxon.org; Chun et al., 2007); relative to all Planococcus species, strain Or ${ }^{\mathrm{T}}$ showed highest $16 \mathrm{~S}$ rRNA gene sequence divergence from Planococcus columbae $\operatorname{PgEx} 11^{\mathrm{T}}(96.4 \%)$ and highest similarity to strains clustering in the same branch, namely Planococcus donghaensis $\mathrm{JH}^{\mathrm{T}}(99.6 \%)$ and Planococcus antarcticus CMS 26or ${ }^{\mathrm{T}}$ (98.8\%). Although these levels of $16 \mathrm{~S}$ rRNA gene sequence similarity are very high, significant differences were found between strain $\operatorname{Orl}^{\mathrm{T}}$ and these two most closely related species.

In particular, DNA-DNA hybridization experiments revealed the unique position of strain $\operatorname{Orl}^{\mathrm{T}}$ relative to Planococcus antarcticus CMS 26or ${ }^{\mathrm{T}}\left(=\mathrm{DSM} 22276^{\mathrm{T}}\right)$ and Planococcus donghaensis $\mathrm{JH}^{\mathrm{T}}\left(=\mathrm{DSM} 14505^{\mathrm{T}}\right)$. Cells were disrupted by using a French pressure cell (Thermo Spectronic) and the crude DNA lysate was purified by chromatography on hydroxyapatite as described by Cashion et al. (1977). DNA-DNA hybridization was carried out as described by De Ley et al. (1970) and Huß et al. (1983) by using a UV/VIS spectrophotometer equipped with a Peltier-thermostatted cell holder (Cary 100 Bio). Levels of DNA-DNA relatedness between strain Or $1^{\mathrm{T}}$ and the type strains of Planococcus donghaensis and Planococcus antarcticus were 46.0 and $18.2 \%$, respectively. As the threshold for defining members of the same species according to DNA-DNA relatedness is $\geqslant 70 \%$ (Wayne et al., 1987; Stackebrandt \& Goebel, 1994), these results support the suggestion that strain $\mathrm{Or}^{\mathrm{T}}$ does not belong to either of these phylogenetically related species. Furthermore, the low DNA-DNA hybridization values between strain Or $1^{\mathrm{T}}$ and the type strains of Planococcus donghaensis and Planococcus antarcticus, despite their close relationship at the 16S rRNA gene sequence level, is in accordance with the observations of Nakagawa et al. (1996), who demonstrated that although Planococcus kocurii, Planococcus citreus and Planomicrobium okeanokoites exhibit high $16 \mathrm{~S}$ rRNA gene sequence similarity ( $99 \%$ ), they can be identified as distinct species on the basis of phenotypic differences and low DNA-DNA reassociation values (15-27\%). It should be noted that in our phylogenetic analyses (Fig. 2), the above species are not as similar when compared based on more 


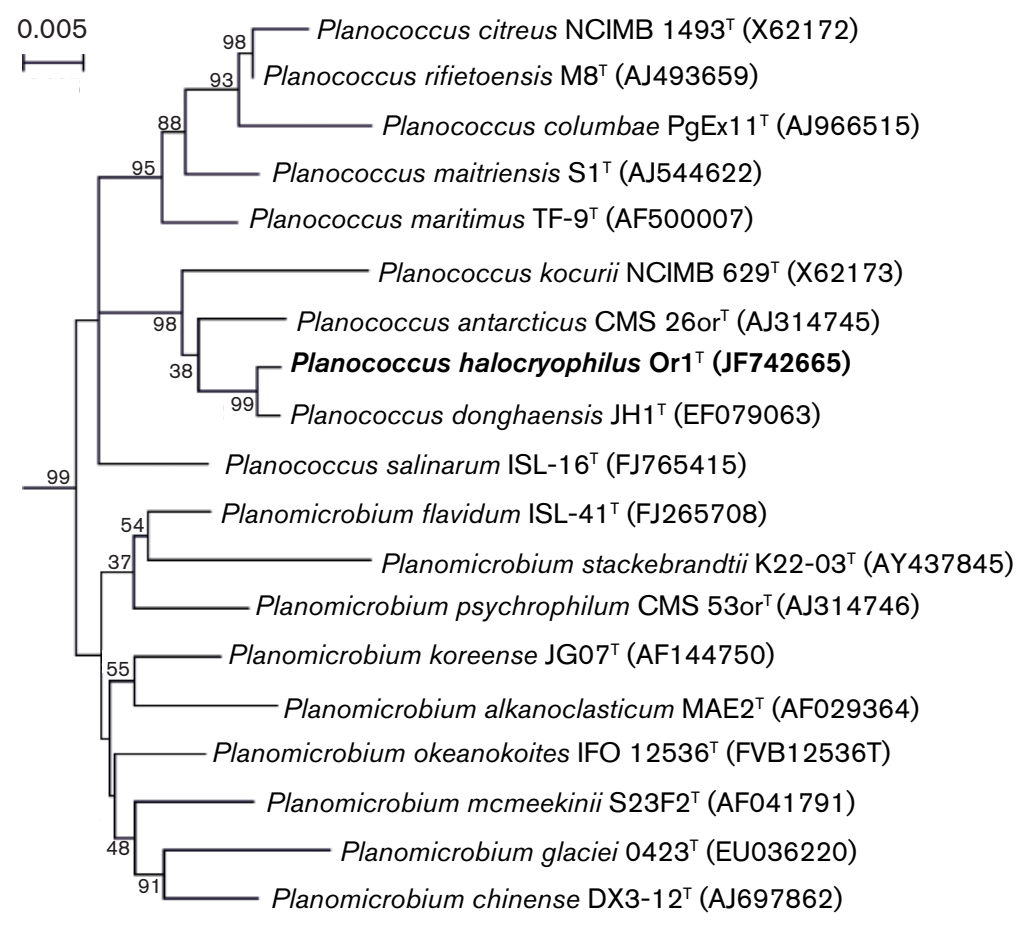

Fig. 2. Neighbour-joining phylogenetic tree based on 16S rRNA gene sequences $(1428 \mathrm{bp})$ showing the position of strain $\mathrm{Or} 1^{\top}$ among related taxa. Bootstrap values (expressed as percentages of 1000 replications) are shown at branch nodes. Similar topologies were recovered in the tree generated with the maximum-likelihood algorithm. The tree was rooted with Exiguobacterium aurantiacum NCDO $2321^{\top}$ (X70316) and Exiguobacterium sibiricum 255-15 ${ }^{\top}$ (CP001022) (not shown). Bar, 0.005 substitutions per nucleotide position.

complete sequence information, yielding lower values as determined via the EzTaxon database (96.8-97.6\% 16S rRNA gene sequence similarity). Nonetheless, these data support the disparity observed between high phylogenetic similarity and genome sequence dissimilarity.

Chemotaxonomic characteristics of strain $\mathrm{Or}^{\mathrm{T}}$ included analyses of respiratory quinones, carried out by Dr Brian Tindall, and peptidoglycan structure, which was determined by the Identification Service of the Deutsche Sammlung von Mikroorganismen und Zellkulturen (DSMZ), Braunschweig, Germany. The predominant menaquinones of strain Or ${ }^{\mathrm{T}}$ were MK-7 (55\%), MK-8 (36\%) and MK-6 (9\%). Both MK-7 and MK-8 are included in the description of the genus Planococcus (Nakagawa et al., 1996); however, only one recognized species, Planococcus maritimus, possesses small amounts of MK-6 (Table 1). The menaquinone profiles of strain $\mathrm{Or} 1^{\mathrm{T}}$ and Planococcus maritimus JCM $11543^{\mathrm{T}}$ are more similar to that of Planomicrobium koreense than to those of other Planococcus species, supporting existing evidence that there is heterogeneity and/or cross-over in the properties of the genera Planococcus and Planomicrobium (Yoon et al., 2003; Dai et al., 2005). Peptidoglycan structure determination was carried out as described by Schleifer \& Kandler (1972) with TLC followed by quantitative analysis by GC and GC-MS (320-MS Quadrupole GC-MS; Varian) according to MacKenzie (1987). The peptidoglycan of strain Or $1^{\mathrm{T}}$ was designated type A $4 \alpha$ according to Schleifer \& Kandler (1972), and type A11.33 according to the DSMZ catalogue of strains, and the cross-link peptide was L-Lys-D-Glu. Cellular fatty acid profiles were obtained from cultures of strain $\mathrm{Orl}^{\mathrm{T}}$ harvested from TSB following 3 days of cultivation, determined previously to be the mid- to late exponential growth phase at $25{ }^{\circ} \mathrm{C}$. Fatty acids were extracted and fatty acid methyl esters were prepared according to the standard protocol of the MIDI/Hewlett Packard Microbial Identification System (Sasser, 1990) at Keystone Laboratories, Edmonton, Canada. The fatty acids were separated by using an Agilent GC (model 6890N) and were identified by using Sherlock version 6.0 via the RTSBA6 database. The fatty acid profile of strain Or $1^{\mathrm{T}}$ comprised (each constituting $\geqslant 0.5 \%$ of the total): saturated fatty acids $\mathrm{C}_{16: 0}$ $(7.0 \%)$ and $\mathrm{C}_{18: 0}(2.9 \%)$; branched fatty acids anteiso$\mathrm{C}_{15: 0}(46.2 \%)$, iso- $\mathrm{C}_{15: 0}(1.7 \%)$, anteiso- $\mathrm{C}_{17: 0}(18.3 \%)$, iso- $\mathrm{C}_{14: 0}(1.7 \%)$, iso- $\mathrm{C}_{16: 0}(2.9 \%)$, iso- $\mathrm{C}_{17: 0}(2.3 \%)$, iso$\mathrm{C}_{17: 1} \omega 10 c(0.9 \%)$ and iso- $\mathrm{C}_{18: 0}(1.2 \%)$; unsaturated fatty acids $\mathrm{C}_{16: 1} \omega 7 c$ alcohol $(2.1 \%), \mathrm{C}_{16: 1} \omega 11 c(4.8 \%)$ and $\mathrm{C}_{18: 1} \omega 9 c(0.8 \%)$; and summed feature 4 (iso- $\mathrm{C}_{17: 1}$ and/or anteiso- $\left.\mathrm{C}_{17: 1} ; 5.2 \%\right)$. This profile is similar to those of recognized Planococcus species, although there were differences in the proportions of some fatty acids. Table 2 presents the first compilation of all fatty acid abundance data presented in the literature for the genus Planococcus, with some species showing a broad range, probably due to differences in cultivation conditions and extraction procedures. The DNA G $+\mathrm{C}$ content was determined according the method described by Gonzalez \& Saiz-Jimenez (2002), giving a value of $40.3 \mathrm{~mol} \%$ (mean of three assays). This was in agreement with the $\mathrm{G}+\mathrm{C}$ content obtained from the strain $\operatorname{Or}^{\mathrm{T}}$ genome sequence, calculated as $[\mathrm{G}+\mathrm{C}] /$ $[\mathrm{A}+\mathrm{T}+\mathrm{C}+\mathrm{G}] \times 100(40.5 \mathrm{~mol} \%)$. This falls within the 
Table 2. Cellular fatty acid profile of strain $\mathrm{Or}^{\top}$ compared with those of the type strains of all recognized Planococcus species

Strains: 1, Orl $^{\mathrm{T}}$ (data from this study); 2, P. antarcticus DSM 14505 ${ }^{\mathrm{T}}$ (Reddy et al., 2002); 3, P. kocurii DSM 20747 ${ }^{\mathrm{T}}$ (Hao and Komagata, 1985; Nakagawa et al., 1996; Engelhardt et al., 2001; Yoon et al., 2003); 4, P. maritimus JCM 11543 ${ }^{\mathrm{T}}$ (Yoon et al., 2003; Suresh et al., 2007); 5, P. maitriensis DSM 15305 ${ }^{\mathrm{T}}$ (Alam et al., 2003; Suresh et al., 2007); 6, P. rifietoensis DSM 15069 ${ }^{\mathrm{T}}$ (Romano et al., 2003; Suresh et al., 2007); 7, P. citreus DSM $20549^{\mathrm{T}}$ (Hao \& Komagata, 1985; Nakagawa et al., 1996; Engelhardt et al., 2001; Yoon et al., 2003; Alam et al., 2003; Suresh et al., 2007); 8, P. columbae PgEx11 ${ }^{\mathrm{T}}$ (Suresh et al., 2007); 9, P. donghaensis JH1 ${ }^{\mathrm{T}}$ (Choi et al., 2007); 10, P. salinarum ISL-16 ${ }^{\mathrm{T}}$ (Yoon et al., 2010). Values are percentages of the total fatty acids and only fatty acids comprising $>0.5 \%$ are shown. Ranges are shown for species for which different data are presented in the literature. -, Not detected.

\begin{tabular}{|c|c|c|c|c|c|c|c|c|c|c|}
\hline Fatty acid & 1 & 2 & $3^{*}$ & 4 & 5 & 6 & 7 & 8 & 9 & 10 \\
\hline \multicolumn{11}{|l|}{ Straight-chain } \\
\hline $\mathrm{C}_{14: 0}$ & 0.5 & - & - & - & $0-0.9$ & $0-6.7$ & $0-1.2$ & - & - & - \\
\hline $\mathrm{C}_{15: 0}$ & - & 14 & $6-13$ & $0-3.1$ & $0-2.5$ & $0-7.2$ & $0-6.7$ & - & 1.7 & - \\
\hline$C_{16: 0}$ & 7.0 & 4.2 & $1-2.7$ & $0.8-4.5$ & $6.8-7.2$ & $3.0-17$ & 0-19 & 1.5 & 6.3 & - \\
\hline $\mathrm{C}_{17: 0}$ & - & 1.0 & - & $0-2.5$ & $4.5-5.3$ & - & $0-5.5$ & 1.8 & 1.3 & - \\
\hline $\mathrm{C}_{18: 0}$ & 2.9 & - & $0-2.2$ & - & $0-4.0$ & - & $0-4.9$ & - & - & - \\
\hline \multicolumn{11}{|l|}{ Branched } \\
\hline anteiso- $\mathrm{C}_{14: 0}$ & - & - & - & - & - & $0-7.7$ & - & - & - & - \\
\hline iso- $\mathrm{C}_{14: 0}$ & 1.2 & 1.0 & $6-16$ & $2.1-13$ & $2.4-4.1$ & $0-5.1$ & $1-9.4$ & 11 & 3.4 & 4.2 \\
\hline iso- $\mathrm{C}_{15: 0}$ & 1.7 & 1.3 & $6-14$ & $9.5-23$ & $2.8-5.3$ & $0-18$ & $0-6.7$ & 25 & 4.7 & 2.7 \\
\hline anteiso- $C_{15: 0}$ & 46 & 43 & $40-48$ & $31-38$ & $27-31$ & $43-51$ & $35-62$ & 35 & 44 & 45 \\
\hline iso- $\mathrm{C}_{16: 0}$ & 2.9 & 4.0 & $4-11$ & $4.1-18$ & 9.2 & $5-9.3$ & $2.9-8.6$ & 12 & 9.4 & 7.5 \\
\hline iso- $\mathrm{C}_{17: 0}$ & 2.3 & - & $0-3.0$ & $3.1-7.6$ & - & $0-8.8$ & - & 5 & 6.4 & 2.5 \\
\hline anteiso- $\mathrm{C}_{17: 0}$ & 18 & 9.5 & $2-14$ & $4.4-7$ & $6.6-7.2$ & $5.4-7.6$ & $0-14$ & 4.3 & 16 & 11 \\
\hline iso- $\mathrm{C}_{17: 1} \omega 10 c$ & 0.9 & - & $0-2.5$ & $0.8-4.5$ & - & - & $0-3.2$ & - & 0.7 & 2.0 \\
\hline iso- $\mathrm{C}_{18: 0}$ & 1.2 & - & - & $0-2.1$ & - & - & - & - & 0.4 & 0.5 \\
\hline \multicolumn{11}{|l|}{ Unsaturated } \\
\hline $\begin{array}{c}\mathrm{C}_{16: 1} \omega 7 c \\
\text { alcohol }\end{array}$ & 2.1 & - & $1-11$ & $3.3-8.9$ & $1.6-2.6$ & $0-4.3$ & $0-9.8$ & 4.7 & 1.6 & 17 \\
\hline $\mathrm{C}_{16: 1} \omega 9 c$ & - & - & - & - & $3.8-5.2$ & - & - & - & - & - \\
\hline $\mathrm{C}_{16: 1} \omega 11 c$ & 4.9 & - & $0-2.5$ & $0.6-0.7$ & - & - & $0-9.8$ & - & 1.3 & 1.4 \\
\hline $\mathrm{C}_{18: 1} \omega 9 c$ & - & - & - & - & $0-4.2$ & - & $0-5.6$ & - & - & - \\
\hline Summed feature $4 \dagger$ & 5.2 & 4.2 & - & $1.3-3.1$ & - & - & - & - & 1.9 & 6.0 \\
\hline
\end{tabular}

${ }^{*} \mathrm{C}_{15: 1}$ (double bond position not shown) also present (Nakagawa et al., 1996).

$\dagger$ Summed feature 4 comprises iso- $\mathrm{C}_{17: 1} \mathrm{I}$ and/or anteiso- $\mathrm{C}_{17: 1} \mathrm{~B}$, which could not be separated by GC with the MIDI system.

range of $\mathrm{DNA} \mathrm{G}+\mathrm{C}$ values reported for the genus Planococcus (39-51.2 mol\%, Table 1) (Nakagawa et al., 1996; Yoon et al., 2010).

The physiological, chemotaxonomic and systematic molecular characteristics of strain $\mathrm{Orl}^{\mathrm{T}}$ are similar to those of recognized species of the genus Planococcus (Nakagawa et al., 1996; Yoon et al., 2010; Table 1) and therefore it should be placed in the genus Planococcus. Strain Or ${ }^{\mathrm{T}}$ could be differentiated from recognized Planococcus species based on growth characteristics, namely extreme sub-zero growth and halotolerance, hydrolysis and acid production from various substrates, and its phylogenetic position, which is supported by DNA-DNA hybridization analysis. Therefore, strain $\mathrm{Or}^{\mathrm{T}}$ is considered to represent a novel species of the genus Planococcus, for which the name Planococcus halocryophilus sp. nov. is proposed.

As strain $\mathrm{Or} 1^{\mathrm{T}}$ is able to grow at sub-zero temperatures, it is probably an active member of the active-layer microbial community. Its high halotolerance probably provides the adaptive advantage for surviving within pockets of liquid brine (Deming, 2002), one of the only sources of liquid water at sub-zero temperatures in active-layer and permafrost soils. Although several recognized Planococcus species are psychrotolerant, strain $\mathrm{Orl}^{\mathrm{T}}$ appears to have the broadest growth temperature and salinity range, both necessary traits allowing growth in extreme cryoenvironments.

\section{Description of Planococcus halocryophilus sp. nov.}

Planococcus halocryophilus [ha.lo.cryo.phi'lus. Gr. n. hals halos salt; Gr. n. kruos icy cold; N.L. adj. philus -a -um (from Gr. adj. philos - $\hat{e}$-on) friend, loving; N.L. masc. adj. halocryophilus salt and cold loving, referring to the subzero growth ability and salt-tolerant features of this species and the environment within which it can survive].

Cells are Gram-positive, aerobic, non-spore-forming, motile cocci, $0.8-1.2 \mu \mathrm{m}$ in diameter, and occur singly or 
in pairs. Colonies on TSA are bright orange, opaque, smooth, glistening, of low convexity in the centre, circular and $2.0-3.0 \mathrm{~mm}$ in diameter after 3 days of cultivation at $25{ }^{\circ} \mathrm{C}$. Psychrotolerant; grows at -10 to $37^{\circ} \mathrm{C}$ (optimally at $25{ }^{\circ} \mathrm{C}$ ). Halotolerant; grows in the presence of $0-19 \%$ $\mathrm{NaCl}$, but high salinity is not essential for growth. The growth $\mathrm{pH}$ range is 6.0-11.0, with optimal growth at $\mathrm{pH}$ 7.0-8.0. Utilizes glucose, rhamnose, fructose, glycerol, mannose, galactose, maltose, glucosamine, glutamine, ribose, trehalose, cellobiose, mannitol, sucrose, lactose, lactic acid, pectin, gelatin, dextrin, alanine, serine, arginine, acetic acid, glutamic acid and gluconic acid. Acid is produced from glucose, mannitol, sucrose, rhamnose and L-arabinose. Positive for Tween 80 and gelatin hydrolysis, $\beta$-galactosidase, citrate utilization, arginine decarboxylase, lysine decarboxylase, hydrogen sulfide and indole production. Resistant to tetracycline, polymyxin $B$, penicillin $G$ and erythromycin, but sensitive to troleandomycin, rifamycin SV, mynocycline, lincomycin, vancomycin, nalidixic acid, amoxicillin and streptomycin. The cell-wall peptidoglycan is of type L-Lys-D-Glu, and the predominant menaquinones are MK-7, MK-8 and MK-6. The predominant fatty acids $\left(>10 \%\right.$ of the total) are anteiso- $\mathrm{C}_{15: 0}$ and anteiso- $\mathrm{C}_{17: 0}$.

The type strain, Or $1^{\mathrm{T}}\left(=\mathrm{DSM} 24743^{\mathrm{T}}=\mathrm{JCM} 17719^{\mathrm{T}}\right)$, was isolated from permafrost active-layer soil at Eureka, Ellesmere Island, in the Canadian high Arctic. The DNA $\mathrm{G}+\mathrm{C}$ content of the type strain is $40.5 \mathrm{~mol} \%$.

\section{Acknowledgements}

We thank the NASA Ames drilling team for supporting initial recovery of active-layer and permafrost cores. Funding for this research was provided by the Natural Sciences and Engineering Research Council (NSERC), Canada Research Chair program (CRC), Canadian Foundation for Innovation (CFI), Polar Continental Shelf Program (PCSP) and the Canadian Space Agency (CSA) Canadian Analogue Research Network (CARN).

\section{References}

Alam, S. I., Singh, L., Dube, S., Reddy, G. S. \& Shivaji, S. (2003). Psychrophilic Planococcus maitriensis sp. nov. from Antarctica. Syst Appl Microbiol 26, 505-510.

Cashion, P., Holder-Franklin, M. A., McCully, J. \& Franklin, M. (1977). $A$ rapid method for the base ratio determination of bacterial DNA. Anal Biochem 81, 461-466.

Choi, J.-H., Im, W.-T., Liu, Q.-M., Yoo, J.-S., Shin, J.-H., Rhee, S.-K. \& Roh, D.-H. (2007). Planococcus donghaensis sp. nov., a starchdegrading bacterium isolated from the East Sea, South Korea. Int J Syst Evol Microbiol 57, 2645-2650.

Chun, J., Lee, J.-H., Jung, Y., Kim, M., Kim, S., Kim, B. K. \& Lim, Y. W. (2007). EzTaxon: a web-based tool for the identification of prokaryotes based on $16 \mathrm{~S}$ ribosomal RNA gene sequences. Int J Syst Evol Microbiol 57, 2259-2261.

Dai, X., Wang, Y.-N., Wang, B.-J., Liu, S.-J. \& Zhou, Y.-G. (2005). Planomicrobium chinense sp. nov., isolated from coastal sediment, and transfer of Planococcus psychrophilus and Planococcus alkanoclasticus to Planomicrobium as Planomicrobium psychrophilum comb. nov. and
Planomicrobium alkanoclasticum comb. nov. Int J Syst Evol Microbiol 55, 699-702.

De Ley, J., Cattoir, H. \& Reynaerts, A. (1970). The quantitative measurement of DNA hybridization from renaturation rates. Eur $J$ Biochem 12, 133-142.

Deming, J. W. (2002). Psychrophiles and polar regions. Curr Opin Microbiol 5, 301-309.

Engelhardt, M. A., Daly, K., Swannell, R. P. J. \& Head, I. M. (2001). Isolation and characterization of a novel hydrocarbon-degrading, gram-positive bacterium, isolated from intertidal beach sediment, and description of Planococcus alkanoclasticus sp. nov. J Appl Microbiol 90, 237-247.

Gonzalez, J. M. \& Saiz-Jimenez, C. (2002). A fluorimetric method for the estimation of $\mathrm{G}+\mathrm{C}$ mol\% content in microorganisms by thermal denaturation temperature. Environ Microbiol 4, 770-773.

Hao, M. V. \& Komagata, K. (1985). A new species of Planococcus, P. kocurii isolated from fish, frozen foods, and fish curing brine. J Gen Appl Microbiol 31, 441-455.

Huß, V. A. R., Festl, H. \& Schleifer, K. H. (1983). Studies on the spectrophotometric determination of DNA hybridization from renaturation rates. Syst Appl Microbiol 4, 184-192.

Juck, D. F., Whissell, G., Steven, B., Pollard, W., McKay, C. P., Greer, C. W. \& Whyte, L. G. (2005). Utilization of fluorescent microspheres and a green fluorescent protein-marked strain for assessment of microbiological contamination of permafrost and ground ice core samples from the Canadian High Arctic. Appl Environ Microbiol 71, 1035-1041.

Jukes, T. H. \& Cantor, C. R. (1969). Evolution of protein molecules. In Mammalian Protein Metabolism, vol. 3, pp. 21-132. Edited by $\mathrm{H}$. N. Munro. New York: Academic Press.

Jung, Y.-T., Kang, S.-J., Oh, T.-K., Yoon, J.-H. \& Kim, B.-H. (2009). Planomicrobium flavidum sp. nov., isolated from a marine solar saltern, and transfer of Planococcus stackebrandtii Mayilraj et al. 2005 to the genus Planomicrobium as Planomicrobium stackebrandtii comb. nov. Int J Syst Evol Microbiol 59, 2929-2933.

Junge, K., Gosink, J. J., Hoppe, H. G. \& Staley, J. T. (1998). Arthrobacter, Brachybacterium and Planococcus isolates identified from Antarctic sea ice brine. Description of Planococcus momeekinii, sp. nov. Syst Appl Microbiol 21, 306-314.

Kocur, M., Zdena, P., Hodgkiss, W. \& Martinec, T. (1970). The taxonomic status of the genus Planococcus Migula 1894. Int J Syst Bacteriol 20, 241-248.

Lane, D. J. (1991). 16S/23S rRNA sequencing. In Nucleic Acid Techniques in Bacterial Systematics, pp. 115-175. Edited by E. Stackebrandt \& M. Goodfellow. Chichester: Wiley.

MacKenzie, S. L. (1987). Gas chromatographic analysis of amino acids as the N-heptafluorobutyryl isobutyl esters. J Assoc Off Anal Chem 70, 151-160.

Mayilraj, S., Prasad, G. S., Suresh, K., Saini, H. S., Shivaji, S. \& Chakrabarti, T. (2005). Planococcus stackebrandtii sp. nov., isolated from a cold desert of the Himalayas, India. Int J Syst Evol Microbiol 55, 91-94.

Migula, W. (1894). Über ein neues System der Bakterien. Arb Bakteriol Inst Karlsruhe 1, 235-238 (in German).

Nakagawa, Y., Sakane, T. \& Yokota, A. (1996). Emendation of the genus Planococcus and transfer of Flavobacterium okeanokoites Zobell and Upham 1944 to the genus Planococcus as Planococcus okeanokoites comb. nov. Int J Syst Bacteriol 46, 866-870.

Reddy, G. S. N., Prakash, J. S. S., Vairamani, M., Prabhakar, S., Matsumoto, G. I. \& Shivaji, S. (2002). Planococcus antarcticus and Planococcus psychrophilus spp. nov. isolated from cyanobacterial mat samples collected from ponds in Antarctica. Extremophiles 6, 253-261. 
Romano, I., Giordano, A., Lama, L., Nicolaus, B. \& Gambacorta, A. (2003). Planococcus rifietensis sp. nov., isolated from algal mat collected from a sulfurous spring in Campania (Italy). Syst Appl Microbiol 26, 357-366.

Saitou, N. \& Nei, M. (1987). The neighbor-joining method: a new method for reconstructing phylogenetic trees. Mol Biol Evol 4, 406-425.

Sasser, M. (1990). Identification of bacteria by gas chromatography of cellular fatty acids, MIDI Technical Note 101. Newark, DE: MIDI Inc.

Schleifer, K. H. \& Kandler, O. (1972). Peptidoglycan types of bacterial cell walls and their taxonomic implications. Bacteriol Rev 36, 407-477.

Stackebrandt, E. \& Goebel, B. M. (1994). Taxonomic note: a place for DNA-DNA reassociation and $16 \mathrm{~S}$ rRNA sequence analysis in the present species definition in bacteriology. Int J Syst Bacteriol 44, 846849.

Steven, B., Briggs, G., McKay, C. P., Pollard, W. H., Greer, C. W. \& Whyte, L. G. (2007). Characterization of the microbial diversity in a permafrost sample from the Canadian high Arctic using culturedependent and culture-independent methods. FEMS Microbiol Ecol 59, 513-523.

Steven, B., Chen, M. Q., Greer, C. W., Whyte, L. G. \& Niederberger, T. D. (2008). Tumebacillus permanentifrigoris gen. nov., sp. nov., an aerobic, spore-forming bacterium isolated from Canadian high Arctic permafrost. Int J Syst Evol Microbiol 58, 1497-1501.

Suresh, K., Mayilraj, S., Bhattacharya, A. \& Chakrabarti, T. (2007). Planococcus columbae sp. nov., isolated from pigeon faeces. Int J Syst Evol Microbiol 57, 1266-1271.
Tamura, K., Peterson, D., Peterson, N., Stecher, G., Nei, M. \& Kumar, S. (2011). MEGA5: molecular evolutionary genetics analysis using maximum likelihood, evolutionary distance, and maximum parsimony methods. Mol Biol Evol 28, 2731-2739.

Vali, H., Weiss, B., Li, Y.-L., Sears, S. K., Kim, S. S., Kirschvink, J. L. \& Zhang, C. L. (2004). Formation of tabular single-domain magnetite induced by Geobacter metallireducens GS-15. Proc Natl Acad Sci U S A 101, 16121-16126.

Wayne, L. G., Brenner, D. J., Colwell, R. R., Grimont, P. A. D., Kandler, O., Krichevsky, M. I., Moore, L. H., Moore, W. E. C., Murray, R. G. E. \& other authors (1987). International Committee on Systematic Bacteriology. Report of the ad hoc committee on reconciliation of approaches to bacterial systematics. Int J Syst Bacteriol 37, 463-464.

Yoon, J.-H., Kang, S.-S., Lee, K.-C., Lee, E. S., Kho, Y. H., Kang, K. H. \& Park, Y. H. (2001). Planomicrobium koreense gen. nov., sp. nov., a bacterium isolated from the Korean traditional fermented seafood jeotgal, and transfer of Planococcus okeanokoites (Nakagawa et al. 1996) and Planococcus momeekinii (Junge et al., 1998) to the genus Planomicrobium. Int J Syst Evol Microbiol 51, 1511-1520.

Yoon, J.-H., Weiss, N., Kang, K. H., Oh, T.-K. \& Park, Y.-H. (2003). Planococcus maritimus sp. nov., isolated from sea water of a tidal flat in Korea. Int J Syst Evol Microbiol 53, 2013-2017.

Yoon, J.-H., Kang, S.-J., Lee, S.-Y., Oh, K.-H. \& Oh, T.-K. (2010). Planococcus salinarum sp. nov., isolated from a marine solar saltern, and emended description of the genus Planococcus. Int J Syst Evol Microbiol 60, 754-758. 